\title{
Laboratory Conditions: German-Speaking Volkskunde and the Great War
}

\author{
ReINHARD JOHLER
}

Leo Spitzer was born in 1887 into a prosperous Viennese Jewish family. He took a doctorate in Romance languages at the University of Vienna with a thesis on "Word Coinage as a Stylistic Means on the Example of Rabelais," attaining the status of Privatdozent (just short of professor) at the age of 26. In 1920, he followed his teacher Wilhelm Meyer-Lübke to Bonn. In 1925, he accepted a chair in Romance languages in Marburg and, in 1930 in Cologne. National Socialist persecution drove him first to Istanbul in 1933 and then to Johns Hopkins University in Baltimore. Spitzer died in 1960 in Forte dei Marmi, Italy. The two volumes of Style Studies ${ }^{1}$ are regarded as his magnum opus.

By all accounts, Spitzer made significant contributions to the study of Romance languages. The lasting value of his work is still being debated. One can dismiss him, as Hans Ulrich Gumbrecht does in a biographical essay, as a fashionable but methodologically aimless "high flyer," as the Romance languages scholar Bernhard Hurch of Graz has been doing for years and with ample justification, the founder of discourse analysis. ${ }^{3}$ This is not the place to elaborate on the evidence in favor of the latter, but it includes the translations of Spitzer's works into Italian ${ }^{4}$ and-by no less than Michel Foucault himself-into French, translations which have attained remarkable scholarly

1 Leo Spitzer, Stilstudien (Munich: Hueber, 1928).

2 Hans Ulrich Gumbrecht, "'Methode als Erlebnis': Leo Spitzers Stil," in Vom Leben und Sterben der großen Romanisten:Karl Vossler, Ernst Robert Curtius, Leo Spitzer, Erich Auerbach, Werner Krauss (Munich: Hanser, 2002), 72-152.

3 Bernhard Hurch, "[(Die Suche nach dem Stil) als Text]: Diskursanalytisches zu Gumbrechts Spitzer Buch," Romanische Forschungen 118 (2006): 341-355.

4 Leo Spitzer, Saggi di critica stilistica (Florence: Sansoni, 1985). 
renown. ${ }^{5}$ More directly relevant to the present argument is that Spitzer, just after the First World War, published three monographs in brief succession whose approach can more or less be described as discourse analysis. All three would have been inconceivable without the war. Circumlocutions for Hunger in Italian: Stylistic-Onomasiological Study on the Basis of Unpublished Censorship Materials ${ }^{6}$ was published in Halle, Germany, in 1920; in 1921, a work on Letters of Italian Prisoners of War: Materials for a Characterization of Italian Folk Correspondence ${ }^{7}$ was published in Bonn. In 1922, a unifying synthesis covering much of the same ground, Italian Vernacular Speech, ${ }^{8}$ was published in Bonn and Leipzig.

How might wartime conditions have prompted the "invention" of discourse analysis? As the books' titles imply, Spitzer had access to vast amounts of source material that he, beginning in September 1915-without direct orders, but clearly as an element of his military service-had systematically copied as director of the censorship department of the central registration office [Gemeinsames Nachweisebureau] for Italian prisoners of war (POWs) in Vienna. He subjected the euphemisms that the prisoners used to elicit shipments of food from home without attracting the attention of censors ${ }^{9}$ to meticulous philological analysis, and his researches persuaded him of the "patternedness" of "folk correspondence" and inspired the first scholarly account of Italian vernacular language as a whole. ${ }^{10}$

5 Jean Starobinski, "Leo Spitzer et la lecture stylistique," in Les études de style, ed. Leo Spitzer (Paris: Gallimard, 1970), 7-42.

6 Leo Spitzer, Die Umschreibungen des Begriffes "Hunger" im Italienischen: Stilistisch-onomasiologische Studie auf Grund von unveröffentlichtem Zensurmaterial (Halle a.S.: Niemeyer, 1920).

7 Idem, Italienische Kriegsgefangenenbriefe: Materialien zu einer Charakteristik der volkstümlichen italienischen Korrespondenz (Bonn: Hanstein, 1921).

8 Idem, Italienische Umgangssprache (Bonn: Schroeder, 1922).

9 Italian POWs' complaints of hunger-and their veiled requests for food in letters home-had a specific background: Despite the miserable conditions in the camps, the Italian government-in contrast to its allies-refused to forward supplies, so that prisoners were exclusively reliant on help from their families. Hunger became a central concern for the six hundred thousand Italian POWs, and their mortality rate was correspondingly high. See Giovanna Procacci, "'Fahnenflüchtige jenseits der Alpen': Die italienischen Kriegsgefangenen in Österreich-Ungarn und Deutschland," in Kriegsgefangene im Europa des Ersten Weltkriegs, ed. Jochen Oltmer (Paderborn: Schöningh, 2006), 194-215. The policy background is examined in detail in the informative introduction to the Italian translation of Spitzer's Kriegsgefangenenbriefe: Lorenzo Renzi, "Presentazione," in Lettere di prigionieri di guerra italiani: 1915-1918, by Leo Spitzer (Turin: Boringhieri, 1976), vii-xxxiii.

10 On life and work, see also Bernhard Hurch, "Der Kontext," in Leo Spitzers Briefe an Hugo Schuchardt, ed. idem (Berlin: de Gruyter, 2006), VII-LV. 
Spitzer's office was generally notable for its original scholarship and intellectual productivity. In both his data-gathering and his thinking, he enjoyed the company of a friend, the biologist Paul Kammerer, who was to become famous in the 1920s for a series of experiments eventually exposed as fakescharges that were never entirely disproved. Kammerer's wartime assignments included the systematic iconographic analysis of a "postcard collection"11 assembled by the Italian side for propaganda purposes. His study "Sociological Questions of Captivity as a Prisoner of War"12 included methodologically innovative and theoretically ambitious deliberations on the nature of war that ultimately led him-based on analogies suggested by modern warfare's oftnoted mechanical repetitiveness and regularity-to publish an interesting if perhaps too daring book, The Law of the Series: A Doctrine of the Recurrences in Life and World Events. ${ }^{13}$

For Spitzer and Kammerer, the First World War opened previously unsuspected avenues for systematic collection and analysis. Almost before the first shots were fired, it had begun to appear to both researchers as a tremendous "experiment" that would permit research under "laboratory" conditions more commonly associated with the natural sciences. It is therefore hardly a coincidence that recourse to new methods-perhaps indeed the "invention" of discourse analysis - and the adoption of the serial paradigm of the natural sciences occurred under the unique and novel conditions prevailing in the war.

Kammerer and Spitzer were not the only researchers on whom mass archiving and its potential to facilitate innovative evaluative techniques left a deep impression. Soldiers' letters were collected in large quantities by the "German Folk Song Archive" in Freiburg beginning in $1915^{14}$ and were parsed on both sides of the front by renowned folklorists at their desks in Paris ${ }^{15}$ and German philologists at the POW camp in Chemnitz. ${ }^{16}$ To date, the role of

11 Paul Kammerer, "Meine Ansichtskarten," in Menschheitswende: Wanderungen im Grenzgebiet von Politik und Wissenschaft (Vienna: Der Friede, 1919), 86-97.

12 Idem, "Soziologische Fragen der Kriegsgefangenenschaft," in Menschheitswende, 74-85.

13 Idem, Das Gesetz der Serie: Eine Lehre von den Wiederholungen im Lebens- und Weltgeschehen (Stuttgart: Deutsche Verlags-Anstalt, 1919).

14 John Meier, "Sammlungen deutscher Kriegsbriefe und deutscher Tagebuchaufzeichnungen aus dem Kriege," Mitteilungen des Verbandes deutscher Vereine für Volkskunde 21 (1915): 43-44.

15 Cf. Albert Dauzat, L'Argot de la guerre: D'après une enquête auprès des officiers et soldats (Paris: Colin, 1918); L[azare] Sainéan, L'Argot des tranchées: D'après les lettres des Poilus et les journaux du front (Paris: Boccard, 1915).

16 Willy Hunger, Argot: Soldaten-Ausdrücke und volkstümliche Redensarten der französischen Sprache (Leipzig: Fock, 1917). 
the censor-researcher in the Great War has been as little illuminated as the importance of censorship bureaus as loci of research and collecting. ${ }^{17}$ It is nonetheless apparent that the war was regarded by researchers across Europe as a unique laboratory and an unprecedented opportunity. ${ }^{18}$ The war was seen not only as an original research topic-often charged with patriotic pathosbut also as an ideal opportunity to build careers and refine disciplines. From philology to physics, many sciences absorbed lasting modulations with regard to theory, methods, or source materials, while others were from their inception so intertwined with the war that they can fairly be described as its by-products.

As obvious as the link between scientific progress and a concerted war effort may be ${ }^{19}$ the First World War's generation and transformation of scientific research has been made the subject only of a few rudimentary studies, mostly of disciplines that were firmly entrenched at the outset. ${ }^{20}$ German and

17 Hanns Bächtold-Stäubli, one of the initiators of Kriegsvolkskunde in Switzerland, was employed during the First World War as a military censor. He used his work to gather material for the Handwörterbuch des deutschen Aberglaubens-one of the major postwar projects of German-language Volkskunde. Cf. Christoph Daxelmüller, "Vorwort," in Handwörterbuch des deutschen Aberglaubens, vol. 1 (Berlin: de Gruyter, 1987), v-xxxiv.

18 The ethical questions raised by this particular type of investigation in POW camps have virtually never been addressed. One exception is Romance languages scholar Cesar Foligno of Oxford, who expressed the following judgment in a review: "The mass of material he has collected must have been enormous, judging from the 300 pages of quotations he prints, and if ever a mother was kept waiting a day longer than necessary for news of her son in order that this book could be written, that was a crime for which this book or ten such books, however interesting and learned, would fail to be extenuating circumstances."-Cesare Foligno, review of "Die Umschreibungen des Begriffes 'Hunger' im Italienischen: Stilistisch-onomasiologische Studie," The Modern Language Review 17 (1922): 197-201.

19 Mitchell G. Ash, "Wissenschaft—Krieg-Modernität: Einführende Bemerkungen," Berichte zur Wissenschaftsgeschichte 19 (1996): 69-75. For the anthropological disciplines, cf. David H. Price, Anthropological Intelligence: The Deployment and Neglect of American Anthropology in the Second World War (Durham, NC: Duke University Press, 2008).

20 A selection of works on Germany and France: Annette Becker, Maurice Halbwachs: Intellectuel en guerres mondiales 1914-1945 (Paris: Viénot, 2003); Kurt Flasch, Die geistige Mobilmachung: Die deutschen Intellektuellen und der Erste Weltkrieg (Berlin: Fest, 2000); Martha Hanna, The Mobilization of Intellect: French Scholars and Writers during the Great War (Cambridge, MA: Harvard University Press, 1996); Peter Hoeres, Krieg der Philosophen: Die deutsche und britische Philosophie im Ersten Weltkrieg (Paderborn: Schöningh, 2004); Wolfgang Mommsen and Elisabeth Müller-Luckner, eds., Kultur und 
Austrian Volkskunde, on the other hand, was a discipline that had arisen late in the nineteenth century, not in universities but in anthropological societies and clubs, and which was establishing itself one step at a time. The young discipline saw itself as poised to handle whatever the war might bring. Kammerer, in his preliminary evaluations of letters from Italian POWs, spoke of "hidden treasures" and "all kinds of trivialities" that it would be the task of a "future science of culture" to appreciate. ${ }^{21}$ With its nimble creative minds and insatiable collecting, the fresh and innovative discipline of Volkskunde seemed to him-as it seemed to Spitzer and a great many other scholars ${ }^{22}$ - uniquely well positioned to take advantage of the war. Indeed, Spitzer's publications were received with eager curiosity by journals of Volkskunde and regarded by Volkskunde scholars as highly relevant to their work. ${ }^{23}$

\section{Kriegsvolkskunde(n)—War Folklore(s)}

The First World War brought renewed public attention to cultural expressions that had been regarded as premodern or long forgotten-wartime superstitions, prophecies of war and peace, protective amulets, "soldierly" humor on the battlefield, and primitive folk art in the trenches. ${ }^{24}$ Across Europe, Volkskunde sought to profit from the unexpected boom in interest and the surfeit of source materials. Scholars jockeyed for intellectual leadership in the organization of events and collecting and publishing activities that had-for reasons propagandistic, patriotic, and scientific-been initiated by stakeholders ranging from the General Staff to the mass media to individual hobbyists. A niche product originally developed in neutral Switzerland, "Soldatische Volkskunde" quickly became a model for German and Austro-Hungarian "Kriegsvolks-

Krieg: Die Rolle der Intellektuellen, Künstler und Schriftsteller im Ersten Weltkrieg (Munich: Oldenbourg, 1996); Klaus Schwabe, Wissenschaft und Kriegsmoral: Die deutschen Hochschullehrer und die politischen Grundfragen des Ersten Weltkrieges (Göttingen: Musterschmidt, 1969).

21 Kammerer, "Meine Ansichtskarten," 97.

22 The Hamburg art historian Aby Warburg was also particularly intrigued by the collecting of wartime folklore and related themes, see Gottfried Korff, ed., Kasten 117: Aby Warburg und der Aberglaube im Ersten Weltkrieg (Tübingen: Tübinger Vereinigung für Volkskunde, 2008).

23 [Theodor] Siebs, review of "Spitzer, Prof. Dr. Leo, Italienische Umgangssprache," Mitteilungen der Schlesischen Gesellschaft für Volkskunde 25 (1924): 262.

24 Cf. Gottfried Korff, ed., Kleines aus dem Großen Krieg: Metamorphosen militärischen Mülls (Tübingen: Tübinger Vereinigung für Volkskunde, 2002). 
kunde," French "folklore de guerre," Italian "folklore di guerra," and a comparatively weak British "folklore of the war."25

In the following, Kriegsvolkskunde will be introduced in some detail and then, using a comparative approach-without neglecting its nineteenth century parent, anthropology ${ }^{26}$ - situated within the developmental process that eventually produced the various European Volkskunden, ethnologies, and anthropologies. The chief aims are to explore how, on the one hand, anthropological/ethnological/Volkskunde studies germinating in the late nineteenth century ${ }^{27}$ were mobilized for and altered by the war effort, and, on the other hand, how wartime mobilization-with results that varied slightly in different parts of Europe-brought about the eventual institutionalization of the subdisciplines physical anthropology, prehistory and ancient history, Volkskunde, and Völkerkunde/non-European ethnology.

Gottfried Korff recently prepared an admirably hesitant and cautious survey of Kriegsvolkskunde, concentrating on Germany. He argues that the relationship between the wars of the nineteenth and twentieth centuries and the origins of Volkskunde as a science have not yet been adequately explored. He suggests that it cannot be ruled out that the First World War-and the ad hoc discipline of Kriegsvolkskunde with its large-scale collecting projects-served to boost the autonomy of university Volkskunde departments. But although the war, and in particular its outcome, had palpable repercussions for the field of Volkskunde (not the least of which was the publication of the Handbook of

25 On British folklore studies in particular, see R. R. Marett, "Presidental Address: War and Savagery," Folklore 26 (1915): 10-27.

German and especially Austrian Volkskunde developed in the late nineteenth and early twentieth century from anthropological societies that had been founded only a few decades earlier. On the "Berliner Gesellschaft für Anthropologie, Ethnologie und Urgeschichte," see Annette Lewerentz, "Rudolf Virchow als Anthropologe und seine Bedeutung für die Berliner Gesellschaft für Anthropologie, Ethnologie und Urgeschichte," in Zwischen Charité und Reichstag: Rudolf Virchow; Mediziner, Sammler, Politiker, ed. Geraldine Saherwala, Thomas Schnalke, Konrad Vanja, and Hans-Joachim Vogel (Berlin: Museumspädagogischer Dienst, 2002), 123-137; on "Anthropologischen Gesellschaft in Wien," see Karl Pusman, Die "Wissenschaften vom Menschen" auf Wiener Boden (1870-1959): Die Anthropologische Gesellschaft in Wien und die anthropologischen Disziplinen im Fokus von Wissenschaftsgeschichte, Wissenschafts- und Verdrängungspolitik (Münster: LIT, 2008).

27 On the divergent development of Volkskunde in Europe, see Tamás Hofer, "National Schools of European Ethnology and the Question of 'Latent Ethnicity,'" Ethnologia Europaea 26 (1996): 89-96; Thomas Schippers, "A History of Paradoxes: Anthropologies of Europe," in Fieldwork and Footnotes: Studies in the History of European Anthropology, eds. Han V. Vermeulen and Arturo A. Roldán (London: Routledge, 1995), 234-246. 
German Superstition as a follow-up to the questionnaires that had been administered to soldiers during the war), one should use caution in positing sustained effects or even middle-term survival for Kriegsvolkskunde:

Volkskunde during the First World War pounced on these source materials, but admittedly without benefiting in terms of either productivity or argumentation. The diversity of collecting and archiving endeavors led only in the most infrequent cases to the development of typologies amenable to continued use, analyses of objects, or methodological reflections. The diffuse nature of the discipline's selfunderstanding, the reality of industrialized trench warfare that had been transformed during the war, but first and foremost the outcome of the war had a disillusioning effect on the investigative and collecting enterprises that had begun with such élan and enthusiasm. The political and societal transformations of the years 1918-1919 "molded, repressed, channeled, and in short altered" (R. Koselleck) the new scientific field of activity that had arisen during the war. ${ }^{28}$

One can, on the whole, share this appraisal while agreeing that it deserves additional elaboration. Both the outward structure and the internal differentiations in the total European disciplinary map of anthropology/ethnology/ Volkskunde are incomprehensible without a precise look at the First World War, which was, after all, for a long time an intra-European conflict. But first it will be necessary to let some light into the neglected era's "black box" and sort through its contents, which remained largely unexamined by historians of the discipline.

That such an accounting has not yet taken place in Germany has much to do with a competing interest: In Tübingen, to take one prominent example, unstinting scrutiny was given to Volkskunde's complicity in National Socialism, while the First World War was accorded virtually no essential significance whatever. Thus Hermann Bausinger raised, in the early 1960s, the question of whether National Socialism had not been able to harness "central ideas of this scientific discipline" for its own ends. In the years that followed, the discussion of Volkskunde's National Socialist past ${ }^{29}$ called for by Bausinger produced numerous studies of the ideology of the "folk" as well as investigations of Volkskunde and National Socialism per se. The view that "Volkskunde in the twentieth century" 30 had always been a nationalistic "folkish science" gained increasing currency. Scholars exposed its contributions to the genocides of the

28 Gottfried Korff, "Vorwort," in KriegsVolksKunde: Zur Erfahrungsbindung durch Symbolbildung, ed. idem (Tübingen: Tübinger Vereinigung für Volkskunde, 2005), 9-28.

29 Hermann Bausinger, "Volksideologie und Volksforschung: Zur nationalsozialistischen Volkskunde," Zeitschrift für Volkskunde 61 (1965): 177-204.

30 Utz Jeggle, "Volkskunde im 20. Jahrhundert," in Grundriss der Volkskunde: Einführung in die Forschungsfelder der Europäischen Ethnologie, ed. Rolf W. Brednich (Berlin: Reimers, 2001), 53-75. 
1940s in minute detail, ${ }^{31}$ treating the First World War and the years before and after as an ill-starred ideological "prehistory" of little significance for the history of science.

In fact, it is a worthwhile exercise to consider a considerably more significant role for the First World War in the European-and German-development of Volkskunde. This suggestion will be substantiated in six separate remarks that correspond roughly to six major influences released by the war that drove the discipline's development and modification, particularly in the cases in which it achieved institutionalization as a university department. Volkskunde, in summary, chose an independent and, above all, empirically dense path, with aspirations that recall Eduard Spranger's 1914 declaration that the mission of the university was "to interpret the new time, to-as one used to say-'set' it in thoughts." ${ }^{2}$

This conceptual setting - that is: the division of scientific labor that arose during the war-becomes apparent in a report prepared by Otto Mausser, director of the Bavarian dictionary archive in the Royal Bavarian Academy of Sciences and chairman of the "Commission for the Collection of German Soldiers' Language." Mausser $^{33}$ had developed two questionnaires on soldiers' slang and had them distributed in the trenches and behind the lines in large numbers. The resulting material would enable the publication of a "Dictionary of Soldiers' Language":

No world war yet in history has, from its inception, preoccupied public opinion and every kind of science to such a degree as the current one. The literature of justification is growing both here and over there into the incalculable, and the literature describing the war has attained a scope that in no wise always stands in proper proportion to its inherent quality. The sciences are no less stimulated in the most diverse ways by the unsettling experience of war that threatens to dislodge all the foundations of life and life-orientation. There will hardly be found a time in the history of German science in which technology, practically and experimentally, worked with such liveliness as in the period of the war from 1914 to 1917. At the same time, the technical literature also grew to a correspondingly high degree. What is true of the technical sciences is also true of the humanities. The war also assigned them a series of tasks that were already being tackled during the time of the field campaigns. Among all the humanities, however, the task of personally observing and collecting the manifold manifestations of the war falls to Volkskunde. ${ }^{34}$

31 Wolfgang Jacobeit, Hannjost Lixfeld, and Olaf Bockhorn, eds., Völkische Wissenschaft: Gestalten und Tendenzen der deutschen und österreichischen Volkskunde in der ersten Hälfte des 20. Jahrhunderts (Vienna: Böhlau, 1994).

32 Eduard Spranger, "Welchen Sinn hat es, jetzt zu studieren?," Akademische Rundschau 3 (1914/15): 142-146.

33 Cf. Otto Mausser, Deutsche Soldatensprache: Ihr Aufbau und ihre Probleme (Strasbourg: Trübner, 1917).

34 Idem, "Der Liederbestand bairischer Truppen im Weltkrieg (1916)," Bayerische Hefte für Volkskunde 4 (1917): 57-136. 
Numerous claims for the discipline can be read between the lines of Mausser's assessment-for instance, the inspiringly novel quality of a world war as Volkskrieg; the high level of propagandistic and scientific interest and the unabashed attempt to exploit the war to consolidate the discipline's status and establish professional reputations. European Kriegsvolkskunde, folklore della guerra or folklore militaire was a confluence of highly divergent interests. Some participants acted alone, some as elements in vast systematized collective endeavors. Some were educated in Volkskunde, others in theology, psychology, literary criticism, anthropology, or musicology. What they all had in common-and this is the first remark-was that they saw Kriegsvolkskunde, because of its direct relation to the war, as for the time being the equal of any other science, including the most recondite technical specializations. On occasion, it was even perceived as such by outsiders.

Its self-styled contemporaneity and equality with various other scientific disciplines has abundant implications. Kriegsvolkskunde may well have arisen to meet substantive needs, but it also originated-and here, already, is the second remark-in a particular kind of war experience. The First World War was understood by countless scholars in virtually every country party to the war as an utterly novel "laboratory" and possibly "unique" scientific opportunity that was "never to return." The war had not merely, as the Swiss scholar of folk tradition Hanns Bächtold had surmised, pushed aside the curtain of civilization and allowed deep "insight into the psychic life of the people as we only seldom experience it so unveiled"35; it had also revealed itself, as the Viennese sociologist and historian Friedrich Hertz pointed out in his 1915 book Rasse und Kultur, to be "the great mixer of races and cultures"36 - and that in a twofold sense: With its territorial conquests and its millions of POWs, the war brought different cultures into contact and created the conditions for ethnographic and anthropological investigation of unfamiliar and culturally "alien" people, while, at the same time, soldiers with the same national allegiances but differing geographical or social origins were thrown together in the trenches and field hospitals. The potential of their nascent "soldierly" culture to become a new object of scientific examination was likewise regarded as "unique."

The third remark: Scientists who took an active part in Kriegsvolkskunde were able to see themselves as contributing to the war effort because the knowledge and advice they could offer might be of use to those wishing a better un-

35 Hanns Bächtold, Deutscher Soldatenbrauch und Soldatenglaube (Strasbourg: Trübner, 1917), 2.

36 Friedrich Hertz, Rasse und Kultur: Eine kritische Untersuchung der Rassentheorien, 2nd rev. ext. ed. (Leipzig: Kröner, 1915), 91.

37 Theodor Imme, Die deutsche Soldatensprache in der Gegenwart und ihr Humor (Dortmund: Ruhfus, 1917). 
derstanding of the troops' behaviors. For example, to condemn the conspicuous rise in superstition both on the battlefield and at home as either a product of scams devised by profiteers or as obsolete or antiquated behavior would have been to beg the question; superstition needed to be understood for a variety of practical reasons, and scholars of Kriegsvolkskunde gave it-depending on their respective concrete disciplinary or national points of departure-a variety of interpretations. What those interpretations had in common was that the researcher's gaze was generally directed right past the amulet, song, or slang term straight into the Volksseele (a "people's soul" conceived as essentially German) or âme populaire ${ }^{38}$ (an orientation toward prelogical thinking). Each phenomenon was viewed as a "survival" or revival of the distant past. At the same time, their interest was focused on the significance of these phenomena for the present day.

For while the war's destructive power was acknowledged-with increasing openness as the war went on, and especially after it had been lost-its creative potential was seen with equal clarity. The Kriegsvolkskunde scholar John Meier, for example, stated that he could hear soldiers' songs becoming "amalgamated" into a "new unity" as "creations of the war." ${ }^{39}$ The war not only revived premodern aspects of culture, it also created new cultural forms, although-Meier added-the "ease with which it arose" would be matched at war's end by the "ease of its disappearance." ${ }^{40}$

Meier's faith in the ease with which wartime cultural phenomena vanish was based on experience of the Franco-Prussian War of 1870-71. It had not been documented by Volkskundler, and accordingly its traces in popular culture had been almost entirely lost. Thus, it was Meier who formulated the central goal of Kriegsvolkskunde: The job of collecting was not primarily to document what the war was destroying, but rather to preserve the new cultural creations arising during the war for future use-whether by the grandchildren of the combatants as a memorial or as an irreplaceable resource for scholarly activity in the postwar world. ${ }^{41}$

Indeed, as the war began, the collecting-and here is the fourth remark-of anything and everything that had to do with soldiers became a regular mania. ${ }^{42}$

38 Cf. Ralph Winkle, "'Connaître à fond l'âme du soldat': Französische Aberglaubensforschung während des Ersten Weltkriegs," in Alliierte im Himmel: Populare Religiosität und Kriegserfahrung, ed. Gottfried Korff (Tübingen: Tübinger Vereinigung für Volkskunde, 2006), 349-370.

39 John Meier, Das deutsche Soldatenlied im Felde (Strasbourg: Trübner, 1916), 5.

40 Idem, Deutsche Soldatensprache (Karlsruhe: Braun, 1917), 12.

41 Karl Wehrhan, "Fragebogen zur Kriegsvolkskunde," Zeitschrift für rheinische und westfälische Volkskunde 13 (1916): 94-96.

42 Susanne Brandt, "Kriegssammlungen im Ersten Weltkrieg: Denkmäler oder Laboratoires d'historie," in "Keiner fühlt sich hier mehr als Mensch...": Erlebnis 
Its pursuit occupied, in addition to the military, the mass media (i.e., with the "Fliegende Blätter"), a great many individuals acting alone, and numerous scientific clubs and associations located primarily in Germany and AustriaHungary, many of them freshly established in the name of Volkskunde. ${ }^{43}$ The structure and the course of those collecting activities cannot be described in detail here; it must suffice to indicate that an impetus of signal importance came in early 1915 from the Swiss Society for Volkskunde. With support from the Swiss military, it distributed a detailed questionnaire to its soldiers-and later to French and German POWs as well-that became the first comprehensive collection of "soldierly Volkskunde." ${ }^{44}$ Thanks to the questionnaire's translation into Italian and French, the collecting initiative was taken up in both Italy and France within months, if only by individual researchers such as Albert Dauzat and Agostino Gemelli.

A 1915 questionnaire on "The Folk Song in War"45 - systematically organized by the Association of German Volkskunde Clubs and then also by the regional Volkskunde associations ${ }^{46}$ - was the first of the German Empire's major collecting efforts that culminated in the compendium of soldier's songs, the aforementioned "soldiers' language," and ultimately in the "Collection of German Soldiers' Traditions and Beliefs." ${ }^{\text {" } 7}$

In Austria-Hungary, by contrast, the collecting of "soldiers' language" remained on the sidelines; an overly strong emphasis on German in the multinational Austro-Hungarian military could have generated substantial friction. Instead, in line with the Empire's multinational character, Austrian Volkskunde collected phenomena in various languages and therefore developed a unique, because multinational, Kriegsvolkskunde. The initiative to collect "Soldier's Songs of the Imperial and Royal Army" began in November of 1915 and led in 1916 to the founding of the "Music-Historical Archive of the Imperial and

und Wirkung des Ersten Weltkriegs, eds. Gerhard Hirschfeld, Gerd Krumeich, and Irina Renz (Frankfurt a. M.: Klartext, 1996), 283-302.

On Austrian Volkskunde, see Herbert Nikitsch, Auf der Bühne früher Wissenschaft: Aus der Geschichte des Vereins für Volkskunde (Vienna: Selbstverlag des Vereins für Volkskunde, 2006), 129-149.

44 Hanns Bächtold, "Volkskundliche Mitteilungen aus dem schweizerischen Soldatenleben: Proben aus den Einsendungen schweizerischer Wehrmänner," Schweizerisches Archiv für Volkskunde 19 (1915): 201-264.

"Das Volkslied im jetzigen Kriege (Fragebogen des Verbandes deutscher Vereine für Volkskunde)," Zeitschrift für österreichische Volkskunde 25 (1915): 392.

46 A typical example: Adolf Spamer, "Der Krieg, unser Archiv und unsere Freunde: Ein Aufruf des Volkskundearchivs des Bayerischen Vereins für Volkskunst und Volkskunde in München," Bayerische Hefte für Volkskunde 2 (1915): 1-72.

47 See summary, Bericht über die Sammlung soldatischer Volkskunde, erstattet vom Verband deutscher Vereine für Volkskunde (Freiburg im Breisgau: C. A. Wagner, 1918). 
Royal War Ministry" and thus to large-scale collecting of soldiers' songs; the staff of the "music-historical headquarters" included Béla Bartok and Zoltán Kodály. ${ }^{48}$ Also deserving of mention are the "Volkskunde of the occupied Balkan territories" ${ }^{\prime 99}$ pursued by Austrian Volkskunde during the war with its own "Balkan expeditions" and the major anthropological and music-historical studies and recording projects carried out in POW camps in 1915 at the initiative of the "Anthropological Society in Vienna," with the support of the Imperial Academy of Sciences. In contrast to their counterparts in Germany, the Austro-Hungarian studies did not focus on the colonial troops of the Allied Powers, but rather on the "peripheral" peoples of the Russian Empire. ${ }^{50}$

The list presented here, however incomplete, testifies to the tremendous rush of collecting activity under the banners of both Volkskunde and anthropology that was generated by the First World War across Europe. It was marked by clear national peculiarities; the organization of collecting activities varied from country to country, and the academic disciplines involved were not the same. Nonetheless-and this will lead to the fifth remark-collecting during the war was a European project ${ }^{51}$ and not, as was often later claimed, the manifestation of a "German Sonderweg." ${ }^{2}$ Across borders-or rather on both sides of the front-researchers used virtually identical questionnaires. They exchanged and compared their findings. They pursued similar lines of inquiry owed by and large to evolutionism, whether with respect to soldiers' physical characteristics or their jargon, songs, superstitions, and prophecies.

48 Cf. Eva Maria Hois, "Völkerverbindend oder national? Die Funktionalisierung des Volksliedes in der Habsburgermonarchie," Jahrbuch des Österreichischen Volksliedwerkes 48 (1999): 130-148.

49 Cf. the chapter by Christian Marchetti in this volume and his "Scientists with Guns: On the Ethnographic Exploration of the Balkans by Austria-Hungarian Scientists before and during World War I," Ab Imperio 8, no. 1 (2007): 165-190.

50 See the chapter by Monique Scheer in this volume.

51 "Abroad, the importance of a collection of soldiers' language has already been acknowledged: L. Sainéan and A. Dauzat in France, Raffaele Corso in Italy, and other researchers in England are more or less officially active. In neutral Switzerland, the language used by Swiss soldiers is being collected with the direct support and at the orders of the high command, and collecting is being conducted at the same time among prisoners of various nationalities. In Austria the Imperial Academy of Sciences is occupied with the task, and in Germany the Association of German Volkskunde Societies has taken the thing in hand and is being supported by various academies and scientific associations." Meier, Deutsche Soldatensprache, 12.

52 This was suggested by Ake Hultkrantz in the early 1960s, cf. Ake Hultkrantz, General Ethnological Concepts (Copenhagen: Rosenkilde and Bagger, 1960). The German collections typically differed only in their higher degree of organization. 
In a similar fashion, the design of methods and procedures also spanned the front, limited only by the specific kind of materials being collected. They ranged from the highly original discourse-analytic methods devised in Vienna to questionnaires - the war's trademark data-gathering technique-distributed and administered by a great variety of organizations, scientific "expeditions," individual observations conducted in military hospitals, and, in the case of the Italian, Gemelli, even field research on the front lines. ${ }^{53}$ The anthropologicalmusicological investigations in the POW camps were also technically more elaborate and possibly more innovative, combining the moving image, still photography, and phonographic recordings. Whether the "camp studies" constituted a form of early field research in some limited sense is debatable, but, in any case, the POW-camp setting, as Monique Scheer has shown, became known as a space that permitted the application of serialized methods and the latest technologies. ${ }^{54}$

The scope of the data and materials collected was enormous, as were response rates for the various questionnaires, so that, while the war lasted, publication of findings was almost exclusively limited to interim reports and initial summary outlines. ${ }^{55}$ Soldiers' songs that had been submitted were returned to the front in booklet form in hopes both of improving morale and of eliciting additional material. With the armistice-and this leads to the sixth and final remark-monographs on topics within Kriegsvolkskunde and studies conducted in POW camps began appearing in Italy, ${ }^{56}$ France, ${ }^{57}$ and in Germanlanguage publications. ${ }^{58} \mathrm{~A}$ series of doctoral theses exploited the large collections that had been amassed and with no shortage of theoretical ambition. But generally speaking, interest swiftly waned, and by the end of the 1920s at the very latest, it was gone-if only (this is added as a kind of subordinate clause) to reawaken with a start at the National Socialist takeover and come into its

53 Agostino Gemelli, Il nostro soldato: Saggi di psicologia militare (Milan: Fratelli Treves, 1917).

54 Monique Scheer, "'Völkerschau' im Gefangenenlager: Anthropologische 'Feind'-Bilder zwischen popularisierter Wissenschaft und Kriegspropaganda 1914-1918," in Zwischen Krieg und Frieden: Die Konstruktion des Feindes; eine deutsch-französische Tagung, eds. Reinhard Johler, Freddy Raphaël, Patrick Schmoll, and Claudia Schlager (Tübingen: Tübinger Vereinigung für Volkskunde, 2009), 69-109.

55 Bächtold, Deutscher Soldatenbrauch; Mausser, Deutsche Soldatensprache; Meier, Das deutsche Soldatenlied; idem, Deutsche Soldatensprache.

56 For example: Giuseppe Bellucci, Folklore di guerra (Perugia: Unione Tipografica Cooperativa, 1920).

57 Dauzat, L'Argot de la guerre.

58 Wilhelm Doegen, ed., Unter fremden Völkern: Eine neue Völkerkunde (Berlin: Stollberg, 1925); Arthur Byhan, Arthur Haberlandt, and Michael Haberlandt, eds., Europa und seine Randgebiete (Stuttgart: Strecker und Schröder, 1926). 
own with the Second World War, when it was conducted in the same countries, and in many cases by the same researchers, but under circumstances that had changed radically. ${ }^{59}$

\section{Consequences of War}

Why then, the question becomes, did the war era's vast collections of materials and data cease to interest German-speaking scholars so very quickly and, with only a few exceptions, experience no more scientific interpretation? The answer is threefold. One reason was in a sense practical: Defeat had not only made the original goal of collection-documentation of the new soldierly culture-obsolete; it had also, in some cases, put the collections themselves at risk. Otto Mausser, for example, complained that a considerable portion of the Bavarian "collections [of soldiers' language] had been irretrievably lost through the incomprehension of northern German revolutionaries in the year 1918." ${ }^{60}$ More importantly, to continue the multinational collecting activities as they had been conducted, for instance in Austria-Hungary, no longer made sense in the new postimperial regime of diminished nation-states; they were therefore put aside or divided between the participating disciplines. Secondly, scientists increasingly became disillusioned with the Kriegsvolkskunde collections. It seemed to many in retrospect that central basic assumptions of their collecting endeavors had been wrong. For example, it was soon generally accepted that the war-which had proved not to be a Volkskrieg after all-had not given birth to a folk poetry of the war ("volksläufige Soldatendichtung"). The soldiers' lack of productivity, scholars now claimed, should have come as no surprise, since urban proletarians had dominated the ranks. ${ }^{61}$ Thirdly, while a lack of theoretical skills had hardly hindered collecting-and probably even facilitated it - analysis of the resulting flood of material presented tremendous difficulties. It was thus not subjected to renewed attempts. ${ }^{62}$

But, in spite of those caveats with regard to findings, it would be shortsighted to see, in the diverse activities that were carried on in the name of Kriegsvolkskunde, merely a mania for collecting and storage with few tangible

59 Bernhard Schwertfeger and Erich Otto Volkmann, eds., Die deutsche Soldatenkunde, vol. 1 (Leipzig: Bibliographisches Institut, 1933).

60 Otto Mausser, "Die deutsche Soldatensprache," in Schwertfeger and Volkmann, Deutsche Soldatenkunde, 400-425.

61 Wilhelm Hansen, "Das Soldatenlied," in Schwertfeger and Volkmann, Deutsche Soldatenkunde, 426-472.

62 For a detailed account, see Reinhard Olt, Krieg und Sprache: Untersuchungen zu deutschen Soldatenliedern des Ersten Weltkriegs, 2 vols. (Giessen: Schmitz, 1981/82). 
results. Instead, one should support the view of Christine Beil, whose investigation of the "exhibited world war" discovered innovative forms of presentation that are still in use today. ${ }^{63}$ One must also agree with Gottfried Korff, ${ }^{64}$ who places several major international (the Volkskundliche Bibliographie, the Handbook of German Superstition, the First International Folk Art Congress in 1928 in Prague initiated by the League of Nations) as well as national (above all the Atlas of German Volkskunde ${ }^{65}$ ) forms of cooperation that appeared in the immediate postwar era in the context of Kriegsvolkskunde. Leopold Schmidt surely did not err in seeing in Kriegsvolkskunde a tentative but important contribution to a developing Volkskunde of contemporary life ("Gegenwartsvolkskunde") and a precursor to the study of occupational and regional subcultures that created a more precisely differentiated understanding of the term Volk. ${ }^{66}$ Furthermore, the heated theoretical debates of the 1920s can only be understood in the context of the war. Whether one saw, as Karl Reuschel did in 1920, the existence of an ennobling national Volksseele as having been confirmed by the war ${ }^{67}$ or dismissed plebeian ways as a "primitive Gemeinschaftskultur,"68 as did Hans Naumann, was not merely a bone of contention between Romantics and ethnologists within the field, as Viktor von Geramb claimed in an influential article in 1937; such positions were ultimately traceable to researchers' war experiences and their level of personal involvement in Kriegsvolkskunde.

One more point: The air of the serial and technical that had been noted and pursued with such alacrity by Kriegsvolkskunde-which, to paraphrase Viktor von Geramb, reflected its hopes of becoming a hard science ${ }^{69}$ - had, in combination with the sheer volume of data, led to a multiplication and expansion of methods that favored quasi-experimental and natural-scientific interpretive approaches. One result was that, even before the war had ended, it had gone so

63 Christine Beil, Der ausgestellte Krieg: Präsentationen des Ersten Weltkriegs 19141939 (Tübingen: Tübinger Vereinigung für Volkskunde, 2004).

64 Korff, "Vorwort," in KriegsVolksKunde.

65 Cf. Friedemann Schmoll, Die Vermessung der Kultur: Der "Atlas der deutschen Volkskunde" und die Deutsche Forschungsgemeinschaft 1928-1980 (Stuttgart: Steiner, 2009).

66 Leopold Schmidt, Gegenwartsvolkskunde: Eine bibliographische Einführung (Vienna: Verlag der Österreichischen Akademie der Wissenschaften, 1976), 11.

67 Karl Reuschel, Deutsche Volkskunde im Grundriß, vol. 1 (Leipzig: Teubner, 1920), 12.

68 Hans Naumann, "Bauernhaus und Kornkammer in Litauen: Ein Beitrag zum nördlichen Herd- und Vorhallenhaus," in Primitive Gemeinschaftskultur: Beiträge zur Volkskunde und Mythologie (Jena: Diederichs, 1921), 148-167. It is often forgotten that Naumann, beginning in 1916, was the editor-in-chief of two frontline newspapers in Lithuania.

69 Viktor von Geramb, "Urverbundenheit," Hessische Blätter für Volkskunde 36 (1937): 1-31. 
far as to foreground the category of "race" as an interpretive possibility. By the time the war was over, "race" and its cultural counterpart "Volkstum" appeared to many of the German and Austrian scholars discussed here as the only remaining "reliable basic orientation in the great questions of humanity."70

\section{A New European Disciplinary Map}

Reinhart Koselleck once remarked that the vanquished generally develop more far-reaching historical insights than the victors. Friedrich Lenger, recalling Koselleck's dictum, identifies Germany's defeat in the First World War as the deciding factor in an important innovation in the study of history-Volksgeschichte $^{71}$-and (rightly) draws parallels with its disciplinary neighbor Volkskunde. ${ }^{72}$ Both underwent a rapid "inward turn," setting national limits to both their subject matter and their channels of communication. That this occurred in Germany can be seen as the continuation of a "völkisch" trend that had been gaining strength since the turn of the century. ${ }^{73}$ In Austria, despite its territorial losses, the multinational tradition of imperial-and-royal Volkskunde ${ }^{74}$ remained in effect, if in a weakened form. ${ }^{75}$

70 Phrased approximately thus by the doyen of Austrian Volkskunde Michael Haberlandt in his eulogy for the initiator of the POW studies, Rudolf Pöch: Michael Haberlandt, "Nachruf auf Prof. Dr. Rudolf Pöch," Mitteilungen der Anthropologischen Gesellschaft in Wien 51 (1921): 12-13.

71 Willi Oberkrome, Volksgeschichte: Methodische Innovation und völkische Ideologisierung in der deutschen Geschichtswissenschaft 1918-1945 (Göttingen: Vandenhoek und Ruprecht, 1993); Lutz Raphael, ed., Von der Volksgeschichte zur Strukturgeschichte: Die Anfänge der westdeutschen Sozialgeschichte 19451968 (Leipzig: Leipziger Universitätsverlag, 2002).

72 Friedrich Lenger, "Eine Wurzel fachlicher Innovation? Die Niederlage im Ersten Weltkrieg und die 'Volksgeschichte' in Deutschland-Anmerkungen zu einer aktuellen Debatte," in Kriegsniederlagen: Erfahrungen und Erinnerungen, eds. Horst Carl, Hans-Henning Kortüm, Dieter Langewiesche, and Friedrich Lenger (Berlin: Akademie-Verlag, 2004), 41-55.

73 Bernd Jürgen Warneken, "'Völkisch nicht beschränkte Volkskunde': Eine Erinnerung an die Gründungsphase des Fachs vor 100 Jahren," Zeitschrift für Volkskunde 95 (1999): 169-196.

74 Jurij Fikfak and Reinhard Johler, eds., Ethnographie in Serie: Zu Produktion und Rezeption der "österreichisch-ungarischen Monarchie in Wort und Bild (Vienna: Verlag des Instituts für Europäische Ethnologie, 2008).

75 Reinhard Johler, "Das Ethnische als Forschungskonzept: Die österreichische Volkskunde im europäischen Vergleich," Ethnologia Europaea, eds. Klaus Beitl and Olaf Bockhorn (Vienna: University of Vienna, 1995): 69-101. 
Volkskunde in Germany and Austria did not meet with rapid success in its efforts to achieve institutionalization at the university level, despite having intensified them during the war. A central "Imperial Institute for German Volkskunde" had been called for as early as 1917, but remained unrealized for the duration of the Weimar Republic. ${ }^{76}$ Postwar Volkskunde in both countries narrowed its focus to Volkstum and Heimat-folk traditions and the "homeland" were regarded, on the one hand, as having been devastated by the war, but, on the other, as panaceas for current ills-and attempted to gain a foothold in the universities through the back door via teacher education and instruction in Heimatkunde. ${ }^{77}$ Success came in slow stages, but, by the 1930s, a number of universities employed professors of Volkskunde (e.g., Hamburg, Graz, and Innsbruck) and the autonomy of the field was no longer in doubt.

When both Europe and the overarching discipline are taken as a whole, a pattern emerges: The war had routed the German Empire and done away with the Habsburg monarchy; in what remained of Germany and Austria, as well as the mostly quite small states that succeeded Austria-Hungary, specifically national versions of Volkskunde soon succeeded in establishing a university presence while non-European ethnology languished. In the victorious nations of England, France, and Italy, on the other hand, where wartime collecting had not been pursued with the same dogged intensity, non-European ethnology and social anthropology soon eclipsed Volkskunde. Almost universally, however, in terms of academic sinecures, it was another subdiscipline-physical anthropology - that reaped the spoils of war.

Anthropology, ethnology, Volkskunde: The disciplinary map that the war left behind ${ }^{78}$ was clearly in the making before the turn of the century. But the war did more than confirm existing trends. It put an end to Europe's common scientific culture, effectively killing off the evolutionism that had been popular until then, leaving the academic landscape fractured along national lines. ${ }^{79}$ It

76 Hannjost Lixfeld, "John Meier und sein 'Reichsinstitut für deutsche Volkskunde': Zur volkskundlichen Fachgeschichte zwischen Monarchie und Faschismus," Beiträge zur Volkskunde in Baden-Württemberg 3 (1989): 102-144.

77 The Prussian minister of culture and later first president of the "Emergency Association of German Science" Friedrich Schmidt-Ott was central to the restructuring of the educational system; see Fritz Boehm, "Volkskunde und Schule," in Deutsche Forschung: Aus der Arbeit der Notgemeinschaft der Deutschen Wissenschaft (Deutsche Forschungsgemeinschaft) (Berlin: Verlag der Notgemeinschaft der Deutschen Wissenschaft, 1922), 74-85.

78 A more detailed account: Reinhard Johler, "La guerre, I'ennemi et la Volkskunde," Revue des Sciences Sociales 43 (2010): 116-129.

79 Andre Gingrich, "Liberalism in Imperial Anthropology: Notes on Implicit Paradigm in Continental European Anthropology before World War I," Ab Imperio 8, no. 1 (2007): 224-239. 
helped bring about the dissolution of both the methods and the subject matter that had made up the "old" German liberal anthropology of the nineteenth century. ${ }^{80}$ In 1915, Adolf Spamer had written that the "young" science of Volkskunde was "a science of innumerable questions," a "future science." ${ }^{11}$ Its habit of methodological innovation, in combination with its ethical shortcomings, would eventually pave the way for a different "future science": cultural anthropology imported from the United States.

80 Cf. H. Glenn Penny and Matti Bunzl, eds., Worldly Provincialism: German Anthropology in the Age of Empire (Ann Arbor, MI: University of Michigan Press, 2003); Andrew Zimmerman, Anthropology and Antihumanism in Imperial Germany (Chicago, IL: University of Chicago Press, 2001).

81 Spamer, "Der Krieg, unser Archiv und unsere Freunde," 3. 